\title{
METAGENOMIC INSIGHTS ON SOIL MICROBIOME BIODIVERSITY FROM AN ERODING COASTLINE OF TANJUNG PIAI, JOHOR STATE PARK, MALAYSIA
}

Jeyanny $\mathbf{V}^{1}$, *, Nur-Nabilah $\mathrm{A}^{1}$, Norlia $\mathbf{B}^{1}$, Krishnasamy $\mathbf{G}^{1}$, Lee $\mathrm{SL}^{1}$, Singh $\mathrm{NR}^{2}$ \& MuhammadAmiruddin $\mathbf{Z}^{3}$

${ }^{1}$ Forest Research Institute of Malaysia, 52109 Kepong, Selangor, Malaysia

${ }^{2}$ No. 48, Jalan Wirawati 5, Taman Maluri, 55100 Kuala Lumpur, Malaysia

${ }^{3}$ Taman Negara Johor Tanjung Piai, Jalan Terus, Kampung Tanjung Piai, Serkat, 82030 Pontian, Johor, Malaysia

*jeyanny@frim.gov.my

Submitted July 2020; accepted January 2021

\begin{abstract}
The Tanjung Piai National Park is an important tourist attraction and has been severely affected by erosion and pollution, threatening its soil biodiversity. Microbes in mangroves control various nutrient transformation processes in the ecosystem and their population differ with regards to spatial variation. In our current efforts to elucidate the relationship between soil variables and bacterial population, we analysed high-throughput metagenomic datasets from two sites of an old growth mangrove and a severely eroded intertidal mudflat in Tanjung Piai National Park. Sediment samples were collected at $5-20 \mathrm{~cm}$ depth for analysis. Bacterial communities were investigated by throughput sequencing of the 16S rRNA gene. Soil $\mathrm{pH}$, organic carbon, organic matter and nitrogen content significantly differed at both sites. Bacterial community structure revealed that sediments from both sites were dominated by phylum Proteobacteria (32-58\%), followed by Chloroflexi (6-19\%) and Bacteroidetes (2-5\%). Intertidal mudflats had the highest numbers of operational taxonomic unit, as well as Proteobacteria (47\%), Firmicutes (1\%) and Spriochaetes (4\%) compared with the old growth forest, which recorded the highest Bathyarchaeota (11\%) population. Results revealed the sustenance of observed phylum in the soils of contrasting sites and call for future strategies in elucidating functional analysis of bacterial population in further understanding their roles in mangrove ecosystems.
\end{abstract}

Keywords: Next generation sequencing, bacterial diversity, intertidal mudflats, soil properties, erosion, mangrove microbiome

\section{INTRODUCTION}

Mangroves are found in the tropical and subtropical regions of the world. Forming a substantial belt between land and sea, they are susceptible to tidal change and salinity, enabling exchange of sediments, organic matter and gases between water, land and atmosphere (Hutchings \& Saenger 1987, Duarte et al. 1998, Biber 2006). They are a unique ecosystem supporting various functions that significantly impact coastline protection with vegetation. Mangroves serve as breeding and nursing grounds for aquatic resources, and act as a natural carbon sink, a buffer for heavy metal pollution, and is important in nutrient cycling, providing resources for local community industries and tourism (Hossain et al. 2001, Ong \& Gong 2013, Koh et al. 2018). Besides environmental factors, the productivity of mangroves are also governed by biotic factors. Microfaunal communities such as microorganisms play an important role in maintaining the productivity, conservation and nutrients of this ecosystem (Yan et al. 2015, Jeyanny, Mohamad-Fakhri et al. 2019). Microorganisms influence the nutrient cycling of plants and animals and they partake in various activities related to nitrogen fixation, phosphate solubility, photosynthesis, sulphate reduction and production of other substances.

Current literature on the diversity and ecological functions of bacterial communities found in mangrove ecosystems globally is scarce, even in Malaysia. Some recent workers whom have ventured into the metagenomics study in key areas within Peninsular Malaysia have reported various findings including microbial diversity, microbes with potential for bioremediation, diversity related to managed and rehabilitated mangroves and functional analysis related to 
litter processing and discovery of bioplastics (Ismail et al. 2017, Jeyanny et al. 2020). Soil microbiomes are becoming more important in relation to various functions for present and future technologies. Thus, it is prudent to determine soil physicochemical changes in mangrove environments that influence microbes in contrasting environments such as an area heavily affected by erosion, potential pollutants, and with poor vegetation compared with a pristine area with dense vegetation. Soil chemistry such as $\mathrm{pH}$, organic matter, phosphorus, salinity, cation exchange capacity, exchangeable bases alterations influence the composition and diversity of soil microbiome (Alongi et al. 1993, Sahoo \& Dhal 2009). Understanding the diversity of microbes with relation to sites helps forest managers decide on the possible effective steps for rehabilitation efforts and nutrient cycling for mangrove areas. Exploration of microbial diversity also leads to the identification of promising novel bacteria that can be utilised for bioprospecting. To our knowledge, this is the first study on bacterial diversity in mangrove soils of Malaysia using next generation sequencing metagenomics approach in the vulnerable ecosystem of Tanjung Piai National Park, Johor.

Tanjung Piai is a wetland prone to erosion and pollutants and is governed by the State National Parks. Although being awarded as a Ramsar site, this coastal mangrove of 526 ha has been impacted by various factors (e.g. coastal pollution and eroding banks) that hamper the government's efforts in conservation strategies and ecotourism. Recent works in Tanjung Piai outline its importance in biodiversity and the health of its stand as a Bruguiera-Rhizophora dominated forest, housing important vegetations such as Bruguiera cylindrica, Rhizophora mucronata, R. apiculata and R. stylosa (Tan et al. 2012, AhmadAinuddin \& Sheriza 2019). The Straits of Malacca is an important waterway for cargo ships, exposing Tanjung Piai to hydrocarbon and heavy metal contamination leading to mangrove death and suffocation (Amin et al. 2006, Nur-Hafiza et al. 2020). This wetland experiences severe erosion for several decades despite barrier structures which impacted a shoreline retreat between 2 to $4 \mathrm{~m}^{-1} \mathrm{year}^{-1}$ because of strong currents with speed of 0.5 to $0.8 \mathrm{~m} \mathrm{~s}^{-1}$ (Awang et al. 2014), mainly due to local hydrodynamic conditions and the existence of regular ship traffic along this coastline.
The objective of the present study was to analyse the diversity and composition of bacterial communities in Tanjung Piai, located in Johor, Malaysia by sequencing the DNA marker using the next generation techniques. The idea was to gauge the bacterial population in contrasting areas and determine their site-specific habitat related to soil properties. The study is important to identify and provide baseline data on the bacterial community structure present in this mangrove area, with regard to interaction with different soil physicochemical characteristics. The work is a precursor before further microbial explorations are done to observe the possibility of linking soil microbes with mangrove habitat density. Moreover, this is the first metagenomic study focused on the microbiomes in Tanjung Piai in a degraded and a pristine environment with regard to soil chemistry interactions.

\section{MATERIALS AND METHODS}

\section{Site description}

Tanjung Piai $\left(01^{\circ} 16^{\prime} \mathrm{N}, 103^{\circ} 31^{\prime} \mathrm{E}\right)$ is a national park in Johor with coastal mangroves and intertidal mudflats at the southernmost tip of continental Asia. In order to capture the microbial diversity of Tanjung Piai, we sampled two different locations within the wetland. We selected areas which overlooked the sea and were reported to be degraded by the local authority. A total of six transects with a length of $24 \mathrm{~m}$ were established at both sites. Each transect was placed $5 \mathrm{~m}$ apart, whereby, three transects faced seawards on the intertidal mudflats with sparse vegetation and prone to erosion (PM1, PM2 and PM3), and another three, landwards in the dense vegetation of an old growth mangrove forest parallel to the intertidal mudflats (PT1, PT2 and PT3). The intertidal mudflat area is $1.5 \mathrm{~m}$ deep with very few to sparse vegetation of Avicennia sp. at $0.5 \mathrm{~m}$ high covering $10 \%$ of the mudflats. The old growth forest area is covered with dense vegetation comprising a mixture of Rhizophora sp. and Avicennia sp. with trees ranging from 0.3 to $3 \mathrm{~m}$ height.

\section{Soil sampling and analysis}

Four replicates of soil were collected at $5-20 \mathrm{~cm}$ depth using augers from each transect at a distance of every $6 \mathrm{~m}$. The total number of 
samples from both sites was 24. Samples were inserted into individual ziplock bags and labelled accordingly. After sampling, the auger was cleaned with distilled water to avoid contamination before moving to the next transect. An amount of $0.3 \mathrm{~g}$ of soil was transferred into $2 \mathrm{~mL}$ cryovials in triplicates for each soil sample, giving a total of 72 subsamples. All cryovials were frozen and stored in a portable liquid nitrogen tank for preservation before transporting to FRIM for storage in the Genetic Laboratory and then later outsourced for analysis. Four replicates of composite samples at 5-20 cm depth were collected for each transect and tested for $\mathrm{pH}$, electrical conductivity (EC), organic matter, available phosphorus (Av. P) and nitrogen (N). For soil physico-chemical properties, samples were collected according to horizon designations up to $1.2 \mathrm{~m}$ depth for determination of baseline soil properties, namely, soil $\mathrm{pH}, \mathrm{EC}$, organic carbon (OC), N, Av. P, calcium (Ca), magnesium $(\mathrm{Mg})$, exchangeable potassium $(\mathrm{K})$, cation exchange capacity (CEC), and organic matter. Soil $\mathrm{pH}$ was determined using $\mathrm{pH}$ meter in 1:2.5 soil:water slurry whereas EC was measured in 1:5 soil-water suspension using conductivity meter. We used the Walkley and Black (1934) method to determine $\mathrm{C}$ and Kjeldahl digestion for soil N. Available P was determined following Bray and Kurtz method No.2 (Sharifuddin \& Dynoodt 1981). Exchangeable K, Ca and Mg were extracted using $1 \mathrm{M}$ ammonium acetate calibrated at $\mathrm{pH} 7$ followed by atomic absorption spectrometry while cation exchange capacity (CEC) was determined using leaching method (Thomas 1982).

\section{DNA extraction and sequencing}

Upon arrival at the laboratory, the samples were stored at $-20{ }^{\circ} \mathrm{C}$. All samples were outsourced to a third party for DNA extraction and sequencing procedures. The four replicates from each transect were pooled to represent one sample. Thus, we had one pooled sample to represent a composite biological replicate that may comprehensively characterise the microbial community for each transect, and we had three representatives each for intertidal mudflats and old growth mangroves (PM1, PM2, PM3, PT1, PT2, PT3). Using pooled samples to characterise populations is not only cost effective, but also in some cases, leads to more precise and less biased parameter estimation that occurs with individual samples (Caudill 2010).

Total genome DNA from samples was extracted using CTAB/SDS method. DNA concentration and purity was monitored on $1 \%$ agarose gel. The DNA was diluted to $1 \mathrm{ng} \mu \mathrm{L}^{-1}$ using sterile water. Before pooling was done, we took precautionary measures to make sure all DNA concentrations of pooled samples were of similar values to avoid biasness. A consistent amount of $20 \mu \mathrm{L}$ was taken from the four subsamples per transect to yield the required total volume, i.e. $80 \mu \mathrm{L}$. The pooled DNA samples with the optical density of 1.8-2.0 at the wavelength of 260/280 and concentration of $>1 \mathrm{ng} \mathrm{uL}^{-1}$ were ready for PCR amplification.

\section{Barcoded amplicon sequencing}

The PCR amplification of resolution V3 and V4 of 16S rRNA gene was carried out using specific barcoded primers and Phusion ${ }^{\circledR}$ High-Fidelity PCR Master Mix. The PCR products were quantified using $2 \%$ agarose gel electrophoresis. Samples with bright bands between 400 and $450 \mathrm{bp}$ were chosen for further purification using Qiagen Gel Extraction Kit. The libraries generated with NEBNext ${ }^{\circledR}$ Ultra $^{\mathrm{TM}}$ DNA Library Prep Kit and quantified via Qubit@2.0 Fluorometer and Agilent Bioanalyzer 2100 system were analysed by Illumina platform.

\section{Amplicon sequencing data analysis}

Paired-end reads were assigned to samples based on their unique barcode and truncated by cutting off the barcode and primer sequence. The paired-end reads were assembled using FLASH version 1.2.7 (Reyon et al. 2012). Quality filtering on the splicing sequences, known as raw tags, was performed under specific filtering conditions to obtain high-quality clean tags according to the QIIME version 1.7.0 (Caporaso et al. 2010). The tags were compared with reference database (Gold database) using UCHIME algorithm to detect chimera sequences, which were then removed to obtain effective tags. Sequences analysis of the effective tags were performed using UPARSE v7.0.1001 software (Edgar 2013). Sequences with $\geq 97 \%$ similarity were assigned to the same operational taxonomic units (OTUs). Representative sequence for each OTU was screened for further annotation against SILVA Database using Mothur v1.31.2 software (Kozich 
et al. 2013). MUSCLE v3.8.31 was applied to generate phylogenetic relationship of all OTUs representative sequences. Alpha diversity was conducted to analyse complexity of species diversity for a sample through indices, including observed species, Chao1, Shannon, Simpson, ACE (abundance-based coverage estimator), and Good's coverage estimate. All these indices in our samples were calculated using QIIME version 1.7.0 and displayed with $\mathrm{R}$ software version 2.15.3. For beta analysis, principal component analysis (PCA) was conducted using $\mathrm{R}$ software version 2.15.3 to compare bacterial community structure across all samples.

\section{RESULTS AND DISCUSSION}

\section{Physicochemical properties of soil samples}

The main aim of this study was to analyse the bacterial community structure and composition in sediments of Tanjung Piai mangroves from two distinct areas, which was an intertidal mudflat with sparse vegetation (PM1-PM3) and an old growth forest with dense vegetation (PT1PT3). We anticipated the results to show some differences that may regulate the nutrient cycling dynamics, based on the distribution of vegetation.

Table 1 displays the composite soil chemical characteristics of both plot areas examined at $5-20 \mathrm{~cm}$ depth. There were significant differences in soil properties between both plots for dry $\mathrm{pH}, \mathrm{C}$, organic matter, and $\mathrm{N}$ contents. Soil data revealed that soil $\mathrm{pH}$ of the mudflats was significantly more alkaline (>7.10) compared with the old growth forest which was acidic (5.71). Values for OC which also correlated with organic matter were significantly $58 \%$ higher in the dense vegetation compared to the intertidal mudflats. The levels of $\mathrm{N}$ were also almost twofold higher in the dense vegetation.
Most intertidal mudflats have neutral soil $\mathrm{pH}$ (Mohamad-Fakhri et al. 2017, Jeyanny, MohamadFakhri et al. 2019) as the microenvironment was influenced by frequent tidal inundation whereas areas with mangrove vegetation differed due to litterfall from vegetation that changes the soil $\mathrm{pH}$ to be more acidic and conducive for microbial activities (Alongi et al. 2003, Reef et al. 2010). The input from litterfall also alters the organic matter, $\mathrm{N}$ and $\mathrm{OC}$ values as microbes utilise these elements for various processes such as decomposition, nitrification and denitrification, and transformation (Alongi et al. 1998, Ghizelini et al. 2012).

The old growth forest had increasing $\mathrm{pH}$ values with depth but no changes were observed for the intertidal mudflats (Table 2). Similar to the composite samples (Table 1), changes in OC and $\mathrm{N}$ were detected in both areas at varying depths. Values for $\mathrm{Ca}$ and $\mathrm{Mg}$ in both areas ranged from $11.64-35.41 \mathrm{cmol} \mathrm{kg}^{-1}$ but values for $\mathrm{K}$ were very low, i.e. less than $4.0 \mathrm{cmol} \mathrm{kg}^{-1}$. Range of CEC values ranged between 28.47 and $37.55 \mathrm{cmol} \mathrm{kg}^{-1}$. Soil texture analysis were similar between both areas.

Soils are more acidic at the rhizosphere of trees due to the aerobic layer that allows root respiration and rapid OC or organic matter accumulation which uses oxygen thermodynamically (Barreto et al. 2018). Soil $\mathrm{pH}$ increases with depth when there is a decrease in OC (Bai et al. 2016). Values for $\mathrm{Ca}, \mathrm{Mg}$ and CEC obtained in this study were in agreement with those reported by Jeyanny et al. (2018), and Hossain and Nuruddin (2016) for tropical mangroves. Our results showed that clay and silt values were more than $40 \%$ of the soil texture (Table 2), agreeing to common characteristics of mangroves. It is common for mangroves to have higher concentrations of clay and silt as they facilitate adsorption of nutrients (Mohamad-

Table 1 Selected soil physicochemical properties of study plots at 5-20 cm depth

\begin{tabular}{|c|c|c|c|c|c|c|c|}
\hline Soil property & Dry pH & $\begin{array}{c}\mathrm{EC} \\
\left(\mathrm{mS} \mathrm{cm}^{-1}\right)\end{array}$ & $\begin{array}{l}\mathrm{OC} \\
(\%)\end{array}$ & $\begin{array}{l}\mathrm{OM} \\
(\%)\end{array}$ & $\begin{array}{l}\text { Av. P } \\
(\mathrm{ppm})\end{array}$ & $\begin{array}{c}\mathrm{N} \\
(\%)\end{array}$ & $\begin{array}{c}\text { CEC } \\
\left(\mathrm{cmol} \mathrm{kg}^{-1}\right)\end{array}$ \\
\hline Old growth forest & $\begin{array}{c}5.70 \mathrm{a} \\
(0.2)\end{array}$ & $\begin{array}{c}14.29 \mathrm{a} \\
(0.51)\end{array}$ & $\begin{array}{l}5.75 a \\
(0.29)\end{array}$ & $\begin{array}{c}24.82 \mathrm{a} \\
(0.17)\end{array}$ & $\begin{array}{l}41.55 \mathrm{a} \\
(4.12)\end{array}$ & $\begin{array}{l}0.30 \mathrm{a} \\
(0.01)\end{array}$ & $\begin{array}{c}30.56 \mathrm{a} \\
(0.59)\end{array}$ \\
\hline Intertidal mudflats & $\begin{array}{l}7.10 \mathrm{~b} \\
(0.10)\end{array}$ & $\begin{array}{c}14.30 \mathrm{a} \\
(0.45)\end{array}$ & $\begin{array}{l}2.40 \mathrm{~b} \\
(0.48)\end{array}$ & $\begin{array}{c}23.40 \mathrm{~b} \\
(0.12)\end{array}$ & $\begin{array}{l}40.10 \mathrm{a} \\
(13.07)\end{array}$ & $\begin{array}{l}0.16 \mathrm{~b} \\
(0.01)\end{array}$ & $\begin{array}{c}28.30 \mathrm{a} \\
(2.34)\end{array}$ \\
\hline
\end{tabular}

$\mathrm{EC}=$ electrical conductivity, $\mathrm{OC}=$ organic carbon, $\mathrm{OM}=$ organic matter, Av. $\mathrm{P}=$ available phosphorus, $\mathrm{N}=$ nitrogen, $\mathrm{CEC}=$ cation exchange capacity; individual letters in columns denote significant differences at $\mathrm{p}<0.05$ according to $t$-test, values in brackets are standard errors 


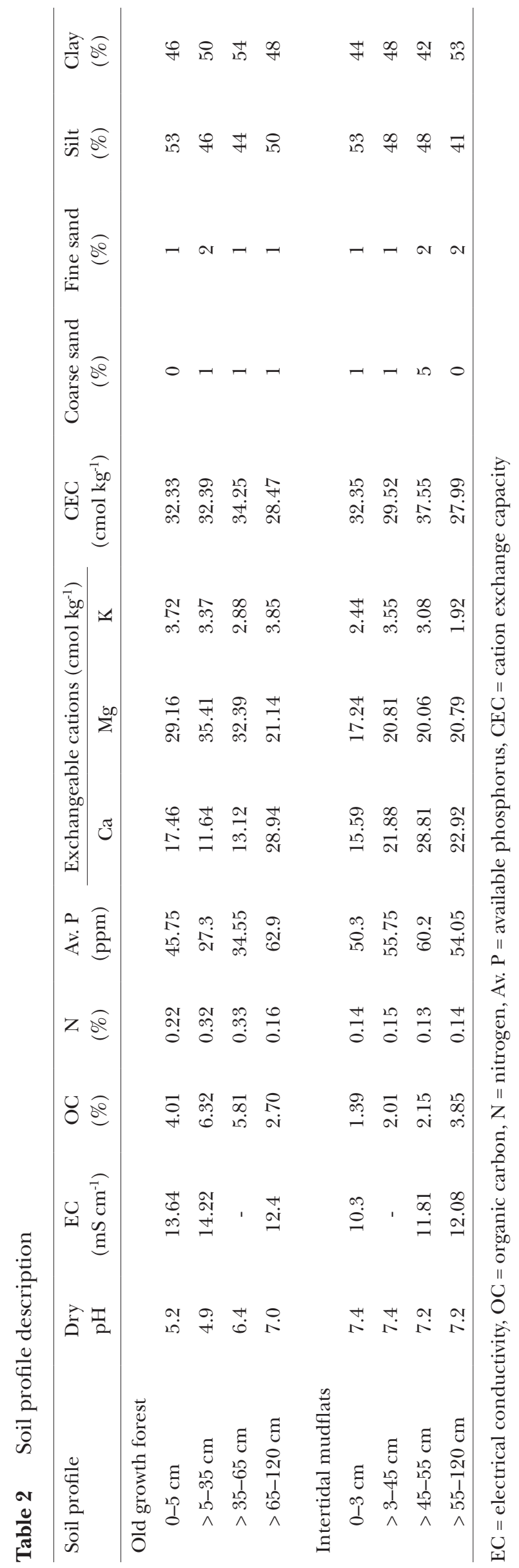


Fakhri et al. 2017), as shown in this study. Increased nutrients also facilitate colonisation of microbial counts (Saravanakumar et al. 2018) leading to favourable CEC and exchangeable bases values.

\section{Amplicon sequencing analysis}

A total of 869,374 raw reads were obtained from the six samples of the intertidal mudflats and old growth forest. After quality trimming, a total of 814,149 clean sequences were $111,117,147,366$, 140,743, 148,755, 138,863 and 127,305 for PM1, PM2, PM3, PT1, PT2 and PT3 respectively (Table 3).

Taxonomic analysis of mangrove metagenomes

The OTUs were defined at a cut-off of $97 \%$ sequence similarity, a commonly recognised level for comparative analysis of 16S rRNA gene (Uroz et al. 2010). Based on the number of OTUs, the total amount of OTUs for mudflats was relatively lower, i.e. 19,370 (PM1-PM3) as compared to 19,729 (PT1-PT3) for dense vegetation samples (Table 4 ). These differences in diversity between samples were confirmed with the Shannon diversity index which was highest for sample PM2. Species richness (Chao1) was greatest for PM1. Good's coverage estimate for the samples ranged from 97.6 to $98.5 \%$, indicating that the sampling was sufficient to cover almost all bacterial communities (Zhang et al. 2017). Generally, there were no differences in community richness (observed species, Chao1 and ACE) and community diversity (Shannon and Simpson) between all samples (Table 4). This showed that both areas (intertidal mudflats and old growth forest) did not display dissimilarities in microbial richness and diversity.

The most abundant phylum in both intertidal mudflats and old growth forest were Proteobacteria (32-58\%), followed by Chloroflexi (6-19\%) and Bacteroidetes (2-5\%) (Figure 1). Proteobacteria was the highest in PM1, Chloroflexi in PM3, Bacteroidetes in PT3 and Bathyarchaeota in PM3. The amount

Table 3 Next generation sequencing statistics

\begin{tabular}{ccccccccc}
\hline Sample & $\begin{array}{c}\text { Total } \\
\text { reads }\end{array}$ & $\begin{array}{c}\text { Combined } \\
\text { reads }\end{array}$ & $\begin{array}{c}\text { Uncombined } \\
\text { reads }\end{array}$ & $\begin{array}{c}\text { Percent } \\
\text { combined } \\
(\%)\end{array}$ & $\begin{array}{c}\text { Combined } \\
\text { base } \\
(\mathrm{bp})\end{array}$ & $\begin{array}{c}\text { Minimum } \\
\text { length } \\
\text { (bp) }\end{array}$ & $\begin{array}{c}\text { Maximum } \\
\text { length } \\
\text { (bp) }\end{array}$ & $\begin{array}{c}\text { Average } \\
\text { length } \\
\text { (bp) }\end{array}$ \\
\hline PM1 & 118,846 & 111,117 & 7729 & 93.50 & $46,735,244$ & 101 & 444 & 421 \\
PM2 & 158,233 & 147,366 & 10,867 & 93.13 & $61,247,422$ & 64 & 444 & 416 \\
PM3 & 152,320 & 140,743 & 11,577 & 92.40 & $57,758,656$ & 64 & 443 & 410 \\
PT1 & 157,126 & 148,755 & 8371 & 94.67 & $62,086,875$ & 229 & 444 & 417 \\
PT2 & 148,312 & 138,863 & 9449 & 93.63 & $57,839,496$ & 64 & 444 & 417 \\
PT3 & 134,537 & 127,305 & 7232 & 94.62 & $53,389,506$ & 122 & 444 & 419 \\
Total & 869,374 & 814,149 & 55,225 & 562.00 & $339,057,199$ & 644 & 2663 & 2500 \\
\hline
\end{tabular}

$\mathrm{PM}=$ intertidal mudflat samples, $\mathrm{PT}$ = old growth mangrove forest samples

Table 4 Comparison of alpha diversity index of 16S rRNA sequencing from mangrove samples

\begin{tabular}{cccccccc}
\hline Sample & OTU & Shannon & Simpson & Chao1 & ACE & Good's & PD_whole_tree \\
\hline PM1 & 5908 & 9.846 & 0.995 & 9534.010 & 8052.069 & 0.976 & 378.222 \\
PM2 & 7601 & 10.790 & 0.998 & 8532.588 & 9002.051 & 0.979 & 475.86 \\
PM3 & 5861 & 9.899 & 0.994 & 6731.545 & 6824.685 & 0.984 & 376.848 \\
PT1 & 7295 & 10.684 & 0.998 & 8258.492 & 8681.637 & 0.979 & 446.188 \\
PT2 & 6520 & 10.413 & 0.997 & 7585.112 & 7756.895 & 0.981 & 419.672 \\
PT3 & 5914 & 10.361 & 0.997 & 6711.347 & 6802.153 & 0.985 & 383.517 \\
\hline
\end{tabular}

$\mathrm{PM}=$ intertidal mudflat samples, $\mathrm{PT}$ = old growth mangrove forest samples; OTU = operational taxonomic unit, Shannon, Simpson, Chao1, ACE, Good's = diversity indices, PD = phylogenetic diversity 
of Chloroflexi was the lowest in PM1 $(6 \%)$ compared with the rest of the samples which ranged from 11-19\%. Overall, the old growth forest had higher amount of Proteobacteria $(47 \%)$, Firmicutes $(1 \%)$ and Spriochaetes (4\%) compared with intertidal mudflats while Bathyarchaeota was higher in intertidal mudflats (11\%) (Figure 2). All other phyla in both intertidal mudflats and old growth forest samples were somewhat similar.

To detect the shared OTUs between the samples, a Venn diagram was plotted (Figure 3) based on the 16S rRNA gene from both areas. The number of shared OTUs between intertidal mudflats and old growth forest was 7366 , amounting to $59.4 \%$, which was more than 2.5 to 3-fold higher than the unique OTUs of intertidal mudflats or old growth forest alone. Generally, the former showed higher number of sequences of 2656 (21.4\%) compared to the latter.

Rarefaction analysis showed that the curves were approaching plateau to the right, indicating that a reasonable number of individual samples had been taken and only the rarest species remained to be sampled (Figure 4). The rarefaction curves showed the OTUs increased with the number of sequences sampled. The distinction between prokaryotic communities of different samples was further augmented at the genus level as can be seen with the rarefaction curves which displayed greater species richness in the rhizosphere soil sediment of intertidal mudflat samples compared with the old growth forest.

The highest community for both sites were from the bacteria group constituting

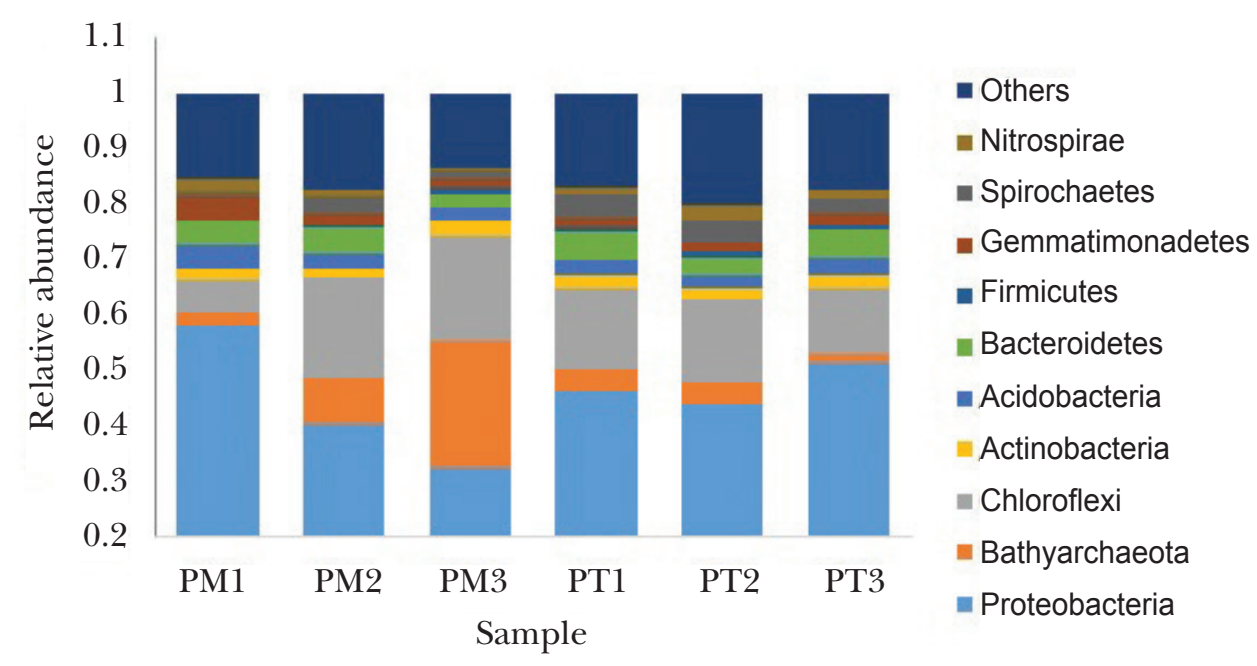

Figure 1 Relative bacterial abundance of the most dominant class operational taxonomic unit according to samples; PM = intertidal mudflat samples, PT = old growth mangrove forest samples

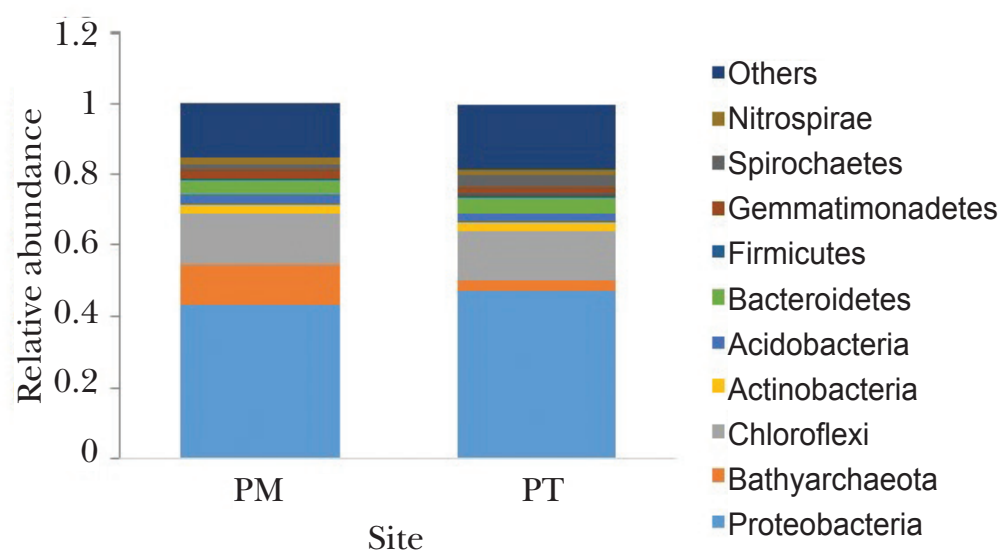

Figure 2 Relative bacterial abundance of the most dominant class operational taxonomic unit according to site; $\mathrm{PM}=$ intertidal mudflat samples, $\mathrm{PT}$ = old growth mangrove forest samples 


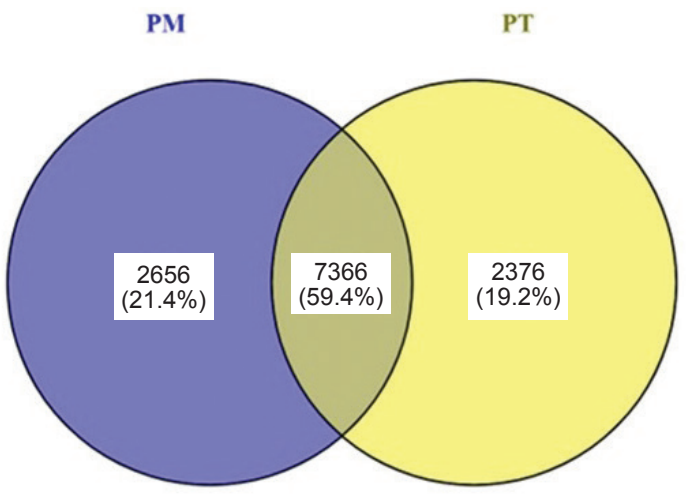

Figures 3 Venn diagram of most abundant share and unique operational taxonomic units at the intertidal mudflats (PM) and old growth forest

about 85 to $95 \%$, followed by Archaea and the rest were unclassified (Figure 5). The PCA was performed to compare differences of the bacterial community between intertidal mudflats and old growth forest (Figure 6). We found that there were significant differences in bacterial community between the intertidal mudflats and old growth forest. Values for PT1-3 were clustered together and samples PM2 and PM3 were in close vicinity except for some deviations for PM1. The close proximity of the geographic locations of the old growth forest explained this data. However, the probability of similar microbial class counts was apparent. There were distinctive changes in soil properties in relation to soil $\mathrm{pH}, \mathrm{OC}$, organic matter and $\mathrm{N}$ between the intertidal mudflats and the old growth mangrove forest (Tables 1 and 2), but these factors did not dominantly influence the microbial diversity of the study area.

Although the old growth mangrove forest showed a relatively higher OTU (Table 4) as compared with the eroded area mudflats, there were no significant differences. Changes in vegetation biomass alter soil organic matter and microbial community (Jeyanny, Norlia et al. 2019), leading to slightly higher microbial count in the mangrove forest. This study confirmed that the number of trees for the old growth mangrove forest (Rhizophora-Avicennia) and the intertidal mudflats (Avicennia) were $388 \mathrm{ha}^{-1}$ and $10 \mathrm{ha}^{-1}$ respectively, similar to values

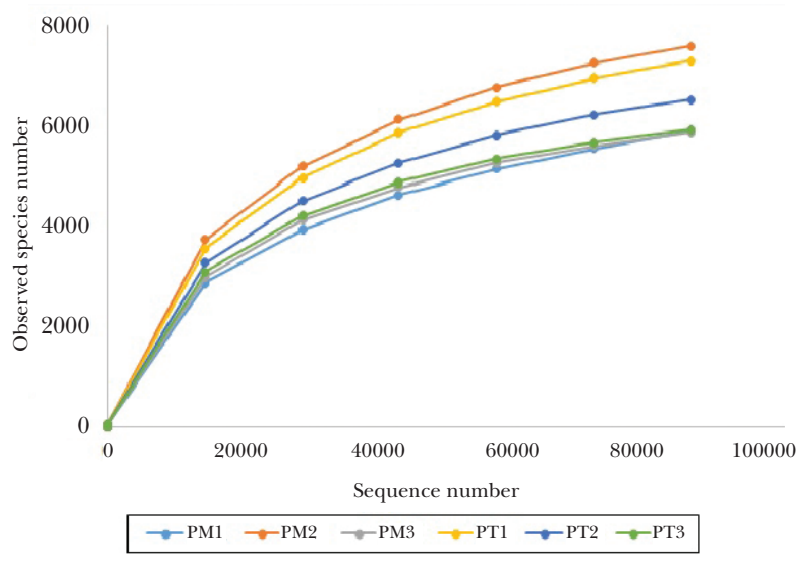

Figure 4 Rarefaction curves generated for $16 \mathrm{~S}$ rRNA pyrosequence from samples collected at intertidal mudflats (PM) and old growth forest (PT); sequences were grouped into operational taxonomic units based on a distance sequence similarity of $97 \%$

reported by Tan et al. (2012) and AhmadAinuddin and Sheriza (2019) in the same area. With regards to species richness (Figure 4), the increased microbial diversity in the intertidal mudflats seemed to suggest the formation of new communities at the rhizosphere of the sparse yet regenerating vegetation. Al-Zubaidy et al. (2016) reported similar increase in microbial diversity that suggested availability of root exudates (i.e. C) for microbe metabolism at the newly regenerating site. Soils in these intertidal areas hold limited vegetation because of the diverse stress caused by continuously changing environmental conditions. However, the unique ecosystem in these areas may harbour a complex yet diverse bacterial community which plays key roles in nutrient cycling. The intertidal zone is also a reservoir of unidentified bacterial taxa that may be explored further. Bacteria in this area are adapted to the harsh environment in the intertidal regions. Their abundance and community composition is important to understand the biogeochemical cycling of nutrients in the soil.

The distribution of Proteobacteria as the most dominant phyla, followed by Chloroflexi, Bacteroidetes and Bathyarchaeota in mangrove sediments (Figures 1 and 2) were concurrent with other findings in Malaysia (Ismail et al. 2017, Jeyanny et al. 2020) and in other subtropical and tropical countries (Dos Santos et al. 2011, Pureza et al. 2012). Proteobacteria 


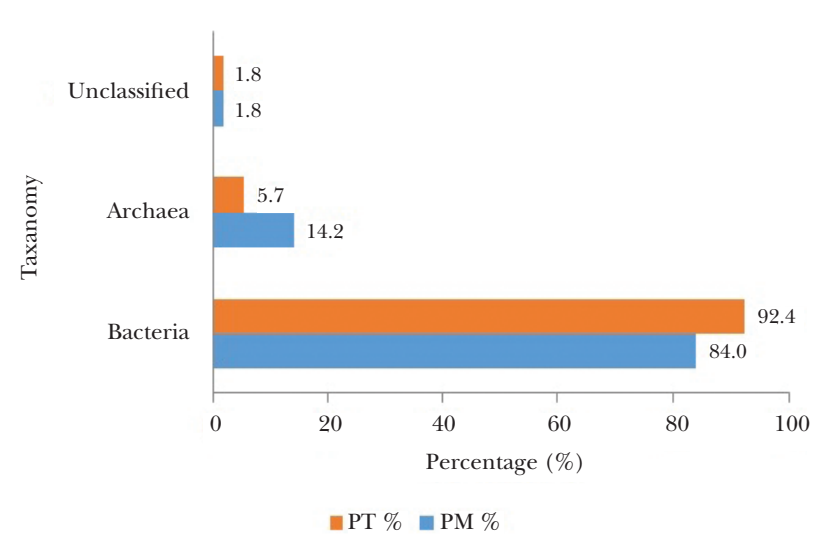

Figure 5 Taxonomy based on domain level (superkingdom) for intertidal mudflats (PM) and old growth forest (PT)

are involved in the cycling of $\mathrm{C}, \mathrm{N}$ and sulfur in the mangrove ecosystem. They are important microbes taking part in nutrient transfer via sulfate reduction (Muyzer \& Stam 2008, Mendes \& Tsai 2014). Bacteroidetes are known to colonise rhizosphere of native mangrove plants with other marine microbes such as Proteobacteria, Firmicutes and Actinobacteria (Fernandes et al. 2014) and are involved in the degradation of organic matter in the ocean (Gomes et al. 2014). Reports have shown that archaeal communities such as Bathyarchaeota has been closely related to gradient in soil $\mathrm{pH}$. The inter-relationship needs to be further explored with regards to its prominence in the PM2 and PM3 samples (Figures 1, 2 and $5)$ as some archaea are known to adapt to acidic conditions and others to neutral to slightly alkaline conditions (Bengtson et al. 2012). Surprisingly, PM2 and PM3 samples also exhibited lower levels of Proteobacteria when Bathyarchaeota phyla were higher, which calls for further investigation of their co-relationship. This situation could have influenced our results for PCA (Figure 4) as clustering for intertidal mudflat samples was not prominent. However, old growth forest displayed satisfactory clustering trends (Figure 4) due to the mature vegetation stand that had lesser influences of tidal inundation which actively displaced microbial distribution compared with intertidal mudflats. Although we expected a distinctive delineation between intertidal mudflats and old

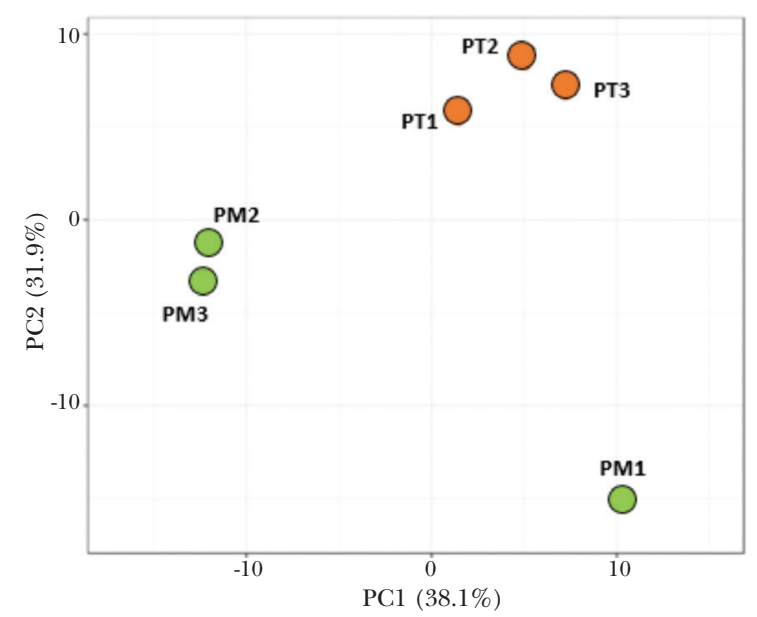

Figure 6 Principal component analysis showing the biological replicates of all samples at the intertidal mudflats (PM) and old growth forest (PT)

growth forest, the Venn diagram proved that the microbial distribution between both plots were almost $60 \%$ similar (Figure 3), rebuking the adverse effects of erosion and pollution on intertidal mudflats as a major factor in governing the bacterial diversity in this site.

\section{CONCLUSIONS}

Based on these findings, we concluded that variations in microbial composition between the old growth forest and intertidal mudflats were minimal, although soil properties at both sites differed significantly for soil $\mathrm{pH}$, OC, organic matter and $\mathrm{N}$. The number of OTUs in the intertidal mudflats was relatively higher and this could be related to the frequent exchange of sediments and microbes due to tides. This study highlighted the resilience of bacterial communities thriving in harsh conditions such as the intertidal mudflats and recommended further probing of this reservoir facilitating numerous ecological functions. There is a need for further understanding the biogeochemical activities spatially and temporally in relation to $\mathrm{C}$ and $\mathrm{N}$ cycles that may influence the distribution of microbes and their functional analysis. Thereafter, these future data may shed some insights on nutrient transformation and enzymatic activities. Pioneer specific bacterial communities that colonise this area need to be considered for future restoration of eroded intertidal mudflats. 


\section{ACKNOWLEDGMENTS}

The field and technical assistance of the FRIM Steering Committee and Soil Management Branch of FRIM are duly acknowledged. We also extend our gratitude to Tanjung Piai Johor National Parks authority for permissions rendered for site access and baseline information on site researched. This work was supported by the joint funding of the Forestry Department of Peninsular Malaysia and Ministry of Energy and Natural Resources (Grant No: 23410207001).

\section{REFERENGES}

Ahmad-Ainuddin R \& Sheriza MR. 2019. Evaluation of Tanjung Piai, Johor mangrove forests to assess sensitivity of plant health index. Pp 163-171 in Tariq-Mubarak $\mathrm{H}$ et al. (eds) Proceedings of the National Seminar on Mangrove $\mathcal{E}$ Coastal Forest 2019. 10-11 September 2019, Sg. Petani.

Alongi DM, Christoffersen P \& Tirendi F. 1993. The influence of forest type on microbial-nutrient relationships in tropical mangrove sediments. Journal of Experimental Marine Biology and Ecology 171: 201-223.

Alongi DM, Clough BF, Dixon P \& Tirendi F. 2003. Nutrient partitioning and storage in arid-zone forests of the mangroves Rhizophora stylosa and Avicennia marina. Trees 17: 51-60. https://doi 10.1007/s00468-0020206-2

Alongi DM, Sasekumar A, Tirendi F \& Dixon P. 1998. The influence of stand age on benthic decomposition and recycling of organic matter in managed mangrove forests of Malaysia. Journal of Experimental Marine Biology and Ecology 225: 197-218. https:/ / doi. org/10.1016/S0022-0981(97)00223-2

Al-Zubaidy H, Essack M, Malas TB et al. 2016. Rhizosphere microbiome metagenomics of gray mangroves (Avicennia marina) in the Red Sea. Gene 576: 626636. http://dx.doi.org/10.1016/j.gene.2015.10.032

Amin B, Ismail A, Arshad A, Yap CK \& Kamarudin MS. 2006. A comparative study of heavy metal concentrations in Nerita lineata from the intertidal zone between Dumai Indonesia and Johor Malaysia. Journal of Coastal Development 10: 19-32.

Awang NA, Jusoh WHW, Hamid MRA. 2014. Coastal erosion at Tanjong Piai, Johor, Malaysia. Journal of Coastal Research 71: 122-130. https://doi: 10.2112/SI71015.1

Bai J, Zhang G, Zhao Q, Lu Q, Jia J, Cui B \& Liu X. 2016. Depth-distribution patterns and control of soil organic carbon in coastal salt marshes with different plant covers. Scientific Reports 6: 34835. https://doi. org/10.1038/srep34835

Barreto CR, Morrissey EM, Wykoff DD \& Chapman SK. 2018. Co-occurring mangroves and salt marshes differ in microbial community composition. Wetlands 38: 497-508. https://doi.org/10.1007/ s13157-018-0994-9
Bengtson P, Sterngren AE \& Rousk J. 2012. Archaeal abundance across a $\mathrm{pH}$ gradient in an arable soil and its relationship to bacterial and fungal growth rates. Applied Environmental Microbiology 78: 5906-5911. https://doi:10.1128/AEM.01476-12

BIBER PD. 2006. Measuring the effects of salinity stress in the red mangrove, Rhizophora mangle L. African Journal of Agricultural Research 1: 1-4.

Caporaso J G, Kuczynski J, Stombaugh J et al. 2010. QIIME allows analysis of high-throughput community sequencing data. Nature Methods 7: 335-336. doi: 10.1038/nmeth.f.303

CaudiLl SP. 2010. Characterizing populations of individuals using pooled samples. Journal of Exposure Science E Environmental Epidemiology 20: 29-37 https:// doi:10.1038/jes.2008.72

Dos Santos HF, Cury JC, Do Carmo FL et al. 2011. Mangrove bacterial diversity and the impact of oil contamination revealed by pyrosequencing: bacterial proxies for oil pollution. PloS One 6: e16943. http:/ / doi:10.1371/journal.pone.0016943

Duarte CM, Geertz-Hansen O, Thampanya U et al. 1998. Relationship between sediment conditions and mangrove Rhizophora apiculata seedling growth and nutrient status. Marine Ecology Progress Series 175: 277-283.

EDGAR RC. 2013. UPARSE: highly accurate OTU sequences from microbial amplicon reads. Nature Methods 10: 996-998.

Fernandes SO, Kirchman DL, Michotey VD, Bonin PC \& LokaBharathi PA. 2014. Bacterial diversity in relatively pristine and anthropogenically-influenced mangrove ecosystems (Goa, India). Brazilian Journal of Microbiology 45: 1161-1171. https://doi. org/10.1590/S1517-83822014000400006

Ghizelini AM, Mendonça-Hagler LCS \& Macrae A. 2012. Microbial diversity in Brazilian mangrove sediments: a mini review. Brazilian Journal of Microbiology 43: $1242-1254$

Gomes NCM, Cleary DFR, Pires ACG et al. 2014. Assessing variation in bacterial composition between the rhizospheres of two mangrove tree species. Estuarine, Coastal and Shelf Science 139: 40-45. http:/ /dx.doi. org/10.1016/j.ecss.2013.12.022

Hossain M, Othman S, Bujang JS \& Tsai LM. 2001. Distribution of copper in the Sepang mangrove reserve forest environment, Malaysia. Journal of Tropical Forest Science 13: 130-139.

Hossain MD \& Nuruddin AA. 2016. Soil and mangrove: a review. Journal of Environmental Science and Technology 9: 198-207. https://doi: 10.3923/jest.2016.198.207

Hutchings P \& Saenger P.1987. Ecology of Mangroves. University of Queensland Press, Queensland.

Ismail Z, SAM CK, YIN WF, CHAN KG. 2017. Tropical mangrove swamp metagenome reveals unusual abundance of ecologically important microbes. Current Science 112: 1698-1703.

Jeyanny V, Mohamad-Fakhri I et al. 2019. Assessing soil health in a newly regenerating mangroves in Sungai Besar, Selangor using geospatial and metagenomics tools. Pp 155-162 in Tariq-Mubarak H et al. (eds) Proceedings of the National Seminar on Mangrove $\mathcal{E}^{\circ}$ CoastalForest 2019. 10-11 September 2019, Sg. Petani. 
Jeyanny V, Norlia B, Getha K et al. 2020. Bacterial communities in a newly regenerated mangrove forest of Sungai Haji Dorani mangroves in the West Coast of Selangor, Malaysia. Journal of Tropical Forest Science 32: 268-282. https://doi.org/10.26525/ jtfs2020.32.3.268

Jeyanny V, Norlia B, TariQ-Mubarak H et al. 2019. Diversiti mikrob tanah di hutan bakau: penemuan awal Sungai Haji Dorani. Pp 83-92 in Abd Latif M et al. (eds) Kejayaan Pemulihan Hutan Bakau Negara. Forest Research Institute Malaysia, Kepong.

Jeyanny V, Siva Kumar B, Ne'ryez SR et al. 2018. Assessing soil quality of a regenerating mangrove forest using geospatial modelling approach. Malaysian Journal of Soil Science 22: 161-173.

Koh HL, Teh SY, Kh'ng XY\& Raja-Barizan RS. 2018. Mangrove forests: protection against and resilience to coastal disturbances. Journal of Tropical Forest Science 30: 446-460.

Kozich JJ, Westcott SL, Baxter NT, Highlander SK \& Schloss PD. 2013. Development of a dual-index sequencing strategy and curation pipeline for analyzing amplicon sequence data on the MiSeq Illumina sequencing platform. Applied and Environmental Microbiology 79: 5112-5120.

Mendes LW \& Tsai SM. 2014. Variations of bacterial community structure and composition in mangrove sediment at different depths in Southeastern Brazil. Diversity 6: 827-843. http://doi:10.3390/d6040827

Mohamad-Fakhri I, Wan-Rasidah K, Rozita A, Jeyanny V \& Nur-Hafiza AH. 2017. Soil nutrient status at open sea mud flat in Sungai Haji Dorani. Pp 299-302. In Zakry et. al (eds) Proceedings of the International Conference on Sustainable Soil Management (SOILS 2017). 4-7 April 2016, Bintulu.

Muyzer G \& Stam AJ. 2008. The ecology and biotechnology of sulphate-reducing bacteria. Nature Reviews Microbiology 6: 441-454. https://doiorg/101038/ nrmicro1892

Nur-Hafiza AH, Wan-Rasidah K, Rosazlin A \& MohamadFAKHRI I. 2020. Heavy metal contamination and ecological risk assessment in sediment of Tanjung Piai mangrove forest. Pp 305-309 in Jeyanny V et al. (eds) Proceedings of the Soil Science Conference of Malaysia 2020. 6-8 October 2020, Johor Bharu.

ONG JE \& Gong WK. 2013. Structure, Function and Management of Mangrove Ecosystems. ISME Mangrove Educational Book Series No. 2. International Society for Mangrove Ecosystems, Okinawa and International Tropical Timber Organization, Yokohama.
Pureza lM, Graças DA, Gonçalves EC, Correa JA, Silva A \& Schneider MP. 2012. Bacterial diversity in an Amazonian mangrove ecosystem. Aquatic Science and Technology 1: 66-85. http://dx.doi.org/10.5296/ast. v1i1.2725

Reef R, Feller IC \& Lovelock CE. 2010. Nutrition of mangroves. Tree Physiology 30: 1148-1160. http:// doi:10.1093/treephys/tpq048

Reyon D, Tsai SQ, Khayter C, Foden JA, Sander JD \& Joung JK. 2012. FLASH assembly of TALENs for high throughput genome editing. Nature Biotechnology 30: 460-465.

Sahoo K \& Dhal NK. 2009. Potential microbial diversity in mangrove ecosystems: a review. Indian Journal of Marine Sciences 38: 249-256.

Saravanakumar K, Kathiresan K, Mubarak Ali D et al. 2018. Soil-microbial communities indexing from mangroves rhizosphere and barren sandy habitats. Physiological and Molecular Plant Pathology 104: 58-68. https://doi.org/10.1016/j.pmpp.2018.09.005

SHARIFUdDIN HA \& Dynoodt RFP. 1981. Basic Guide to Soil and Plant Analysis. Universiti Pertanian Malaysia, Serdang.

TAn DD, Wan J \& Maimon A. 2012. Community structure and productivity of mangrove forests in two National Parks of West Malaysia. Malaysian Forester 75: $165-176$.

Thomas GW. 1982. Exchangeable cations. Pp 159-165 in Page AL et al. (eds) Methods of Soil Analysis. Part 2: Chemical and Microbiological Properties. Second edition. ASA and SSSA, Madison.

Uroz S, Buée M, Murat C, Frey-Klett P \& Martin F. 2010. Pyrosequencing reveals a contrasted bacterial diversity between oak rhizosphere and surrounding soil. Environmental Microbiology Reports 2: 281-288. https://doi.org/10.1111/j.1758-2229.2009.00117.x

WALKLEY A \& Black IA. 1934. An examination of the Degtjareff method for determining soil organic matter and a proposed modification of the chromic acid titration method. Soil Science 37: 29-38.

Yan N, Marschner P, Cao W, Zuo C \& Qin W. 2015. Influence of salinity and water content on soil microorganisms. International Soil and Water Conservation Research 3: 316-323.

Zhang Y, Wang X, Zhen Y, Mi T, He H \& Yu Z. 2017. Microbial diversity and community structure of sulfate-reducing and sulfur-oxidizing bacteria in sediment cores from the East China Sea. Frontiers in Microbiology 8: 2133. https://doi: 10.3389/ fmicb.2017.02133 